\title{
Political Legitimacy in International Border Governance Institutions
}

\section{Introduction}

What kind of normative principles should regulate the governance processes through which migration across international borders is managed? International border governance involves a complex range of political processes for managing the movement of people and goods across the territorial boundaries of states. These incorporate the policy-making and operational activities of individual states, along with the wider regional, international, and non-state institutions that support or constrain states' border governance activities (Global Commission on International Migration 2005). This is one of the most politically controversial areas of international governance, since so many fundamental political values are at stake: the territorial and self-determination claims of national communities; the individual rights of asylum seekers, refugees, and other vulnerable migrant groups; and the potential economic, social and cultural benefits to be gained through carefully managed international mobility. Political controversies arise from disputes about how best to prioritise and pursue these competing values, and normative theories can help resolve these by prescribing systematic regulative principles.

Normative theoretical work on issues of international border governance has so far mostly focused on a set of moral questions concerning what can be called the ethics of exclusion - that is, of excluding individuals, through coercion and other political means, from the benefits of particular political memberships or access to territories. I argue in this paper, however, that this strictly moral theoretical framing obscures another important and politically controversial category of normative questions, concerning what can be called the constitution of control of international borders. These questions ask how best to design institutional infrastructures for controlling international borders, given the functional need for effective cooperation among multiple state and non-state actors alongside 
unilateral state action. They incorporate a range of moral concerns (including those about the ethics of exclusion), but are best understood not as strictly moral questions, but rather as autonomously political normative questions about how best to solve complex institutional collective action problems arising in the context of international border governance.

In what follows I elaborate these distinctive normative questions associated with the constitution of control, and argue that political theorists can help resolve them via the application to border governance institutions of special normative principles of political legitimacy. I develop this argument in three steps. I begin by elaborating in more depth the set of border governance problems linked to the constitution of control, and explaining how these can best be understood as a special category of international collective action problems. Next, I argue that normative analysis of these problems can helpfully be framed by a theoretical conception of political legitimacy in which its normative principles specify the conditions under which individual institutional participants should support the functional operation of an institution, in order for the group to accomplish valuable collective action. Here I explain the sense in which these principles of political legitimacy possess an autonomously political form of normativity, and clarify their relationship to moral principles of justice. In the final section I consider how this normative model of political legitimacy can be applied to help resolve the governance controversies linked to the constitution of control, and I point to some provisional normative prescriptions for international border governance institutions that may follow from it. The key conclusion from this is that theoretical analysis of political legitimacy in border governance institutions warrants further attention from normative theorists than it has thus far received.

Normative controversies in international border governance: From the ethics of exclusion to the constitution of control

Political problems associated with the governance of international borders have been rising in prominence on theoretical agendas over recent years, tracking the growing intensity of political controversies surrounding these problems within 
many liberal-democratic states. As discussed in the introduction to this special issue, however, there are some notable disparities between the normative problems being debated among political theorists, on the one hand, and the sources of controversy within real political communities, on the other (Little and Macdonald this volume). One important source of disparity is that theoretical debates have focused primarily on questions about the moral justifiability of political exclusion, framed in isolation from real background controversies about how best to design and sustain the institutions that are required for any variety of exclusionary policies to be carried out.

The focus of the mainstream justice literature has been guided by the view, articulated bluntly by Michael Blake, that ' $\mathrm{t}$ ] he question of exclusion is the first question to be asked about the morality of immigration' (Blake 2014, 521). This focus on political exclusion directs normative analysis towards the moral justification of both coercive exclusion from politically controlled territory, and social exclusion from a broader set of rights of political membership associated with national citizenship. Debates about the ethics of exclusion address a range of more specific questions concerning moral justifications for: the use of coercion in border control (Abizadeh 2008, Miller 2010); the imposition of political constraints on free movement across states' territories (Carens 1987); the exclusion of non-citizen residents of a territory from a range of political rights enjoyed by citizens (Carens 2013); the principles applied to discriminate among prospective immigrants in selecting candidates for admission (Seglow 2005, Carens 2003); and the principles applied to resolve other kinds of policy controversies associated with exclusionary practices, such as those surrounding the justified conditions for detention of non-citizens (Silverman 2014). As Akakpo and Lenard have recently put it, the framings of these various arguments share a preoccupation with the effort to resolve a 'glaring tension in liberal democratic theory between two competing, yet equally fundamental ideals underpinning liberal democratic societies: a commitment to moral universalism and the ... exclusionary requirement of democracy' (Akakpo and Lenard 2014, 494). 
The questions raised in these debates about the ethics of exclusion are morally weighty, and warrant all the attention within theories of justice that they have received. These moral arguments play some role also within real political debates about border governance among citizens of liberal-democratic states. But their bearing on citizens' normative judgments about what border governance processes to support is limited by the idealised character of their framing assumption: that each sovereign state possesses the institutional capacity to control its borders in accordance with any moral principles its citizens may choose to endorse. Sovereign states do possess an international legal right to exercise exclusionary control over their territorial and political borders, as a core component of the international institution of state sovereignty. But for many states there is a significant gap between this recognised legal right and the material political facts about their institutional capabilities for effective border control. The reality is that the capacity to control borders effectively is an idealised feature of sovereign statehood to which many states aspire, but few can comprehensively achieve.

Some of the wealthiest states have the resources to invest heavily in border control activities, and consequently develop elaborate border control apparatuses. The United States, for example, is reported to spend around $\$ 18$ billion a year on border enforcement activities - including expenditure on sophisticated technologies such as Predator drones, tower-mounted cameras and ground sensors along vulnerable southern borders - a sum which is more than all other federal criminal-law-enforcement agencies combined (Economist 2013). For other states, effective border control is a luxury they cannot afford. Indonesia - to take an example at the opposite end of the capability spectrum - manifestly lacks the resources to control the borders of its archipelago of more than 17,000 islands. These extensive borders are persistently challenged by a stream of irregular migrants passing through en route to Australia, many assisted by well organised people-smuggling networks. Due to the scale of the difficulties involved combatting these irregular migrant flows through its territory, and to their low political priority relative to Indonesia's other economic and social challenges, 
Indonesia has historically accepted the porosity of its borders and invested little in control activities. Under heavy political pressure from Australia these efforts have been strengthened modestly in recent years; though many of the resources for this have been supplied directly by Australia (Missbach 2014).

More broadly, even to the extent that states can exercise effective control over their political borders, they are rarely able to achieve this control unilaterally. Rather, border control confronts states with many institutional challenges that can be met much more successfully through international cooperation. This recognition has pushed many states towards the development of stronger forms of bilateral, regional, and international collaboration and institution-building over the last decade or so, motivated by individual states' desire to secure assistance in securing their own borders, as well as by the collective desire to advance a range of international humanitarian, law-enforcement, social, and economic objectives implicated in the functions of migration governance. Through bilateral channels, many states have pursued what are sometimes called "extra-territorial" or "externalised" border control policies, whereby irregular migrants are intercepted and managed before they reach the territories of their intended destination states. States' extra-territorial border control operations can only be accomplished with the collaborative involvement of third party state agencies, such as immigration authorities and maritime interception authorities (usually military- or police-led), as well as some non-state actors operating within third party state jurisdictions, such as airlines and shipping companies (Brouwer and Kumin 2003, Dench and Crepeau 2003).

At regional levels, states' border control objectives are supported by a range of cooperative governance instruments, developed to strengthen the collective management of shared migration challenges. European Union (EU) states, for example, have cooperated in the development of a strong common external border (Geddes 2005), assisted by the special governance agency Frontex - the 'European Agency for the Management of Operational Cooperation at the External Borders' of the EU, which acts in a coordinating capacity to manage cooperation between EU member states in achieving border security (Pollak and Slominski 2009). In 
regions beyond the $\mathrm{EU}$, there is greater reliance on informal regional dialogues called Regional Consultative Processes on migration (RCPs). These are information-sharing and discussion forums for states interested in promoting greater cooperation in migration governance, and are aimed at building common perspectives and coordinating states' policies and operational activities rather than developing any binding rules for state conduct. There are multiple such RCPs in operation across most geographical regions - prominent examples of which include the Bali Process for Australia, Indonesia, and other South-East Asian states, the Regional Conference on Migration for North and Central American states, and International Dialogues on Migration for both West and Southern African states (Harns 2013).

Despite the development of these external and regional governance initiatives, however, the capacity of states to control their borders is still overall weak. This weakness was a key finding of the Global Commission on International Migration, which reported to the United Nations Secretary-General in 2005 that 'the Commission was struck by the extent to which states and other stakeholders, especially but not exclusively those in less prosperous regions of the world, lack the capacity required to formulate and implement effective migration policies' (Global Commission on International Migration 2005, 2). A key reason for this is that the international governance framework for supporting states' border control activities remains thin and under-developed, with no unifying legal framework, international organisation, or multilateral institutional framework capable of coherently regulating or coordinating state action across different policy and operational problems involved in border control (Betts 2011). As co-founder of the Migration Policy Institute Kathleen Newland has put it:

Migration across borders is recognized as one of the pillars of globalization, and most governments recognize that they cannot control it unilaterally. Yet it is still governed almost entirely at the level of the nation-state (although sometimes in the context of a regional agreement), and states guard that prerogative jealously. (Newland 2010, 331) 
These facts about the limits of states' border control capacities, and the materially and institutionally demanding conditions for their strengthened development, generate a distinctive set of normative questions about border governance. These concern how border governance capabilities should be politically constituted at national, regional, and international levels; as such I call them questions about the constitution of control of international borders. These questions can be posed at different levels of generality. Sergio Marchi, former minister of citizenship and immigration in Canada and former commissioner of the Global Commission on International Migration, has posed the questions in the following very general terms:

Why do we persist with national approaches to a phenomenon that is inherently transnational? How can governments and multilateral agencies enhance their collaboration and cooperation in an effort to develop a more globally shared response? How do we begin to construct an internationally integrated framework, and what are its key elements? (Marchi 2010, 324).

In more concrete terms, these questions concern the design of border governance institutions in several dimensions. First, and most straightforwardly, states confront questions about the way in which decision-making and operational power in border governance should be distributed internally among different functional arms of government. In Australia, to take one example, significant political controversy has surrounded a series of recent legislative developments that shift significant powers in policy and operational matters to executive agencies, stripping asylum seekers of some rights of judicial appeal and giving the government greater powers to detain and remove asylum seekers through military operations on the high seas (Farrell 2014). These measures form part of an international border governance regime, rather than merely domestic migration policies, insofar as they are devised as instruments for both deterring asylum seekers from seeking entry to Australia, and limiting the capacity of asylum seekers' legal and political advocates to influence or interfere with the government's international border control activities. 
In addition to such internal institutional matters, states confront a range of questions about how and on what conditions they should cede decision-making power or operational control over border control matters to external political actors - whether third party states, non-state actors such as private security firms, or regional and international institutions. To take the Australian example again, deep political controversies have been generated by government decisions to shift significant operational responsibilities for asylum-seeker processing and detention activities to third party states - notably Nauru and Papua New Guinea - as well as private firms running detention camps in these offshore locations (Australian Human Rights Commission 2013). More broadly, states face additional questions about how much decision-making authority to shift to regional and international institutional levels. Existing processes are mainly informal and non-binding within regions beyond the $\mathrm{EU}$, and there is significant scope for strengthening these governance processes if states can agree on means by which to do so. At international levels there is even greater scope for the development of more effective governance architectures, given the existing weakness of the international migration regime. Here, a range of institutional options are available with varying governance functions, including negotiating bodies, standard-setting bodies, regulatory agencies, monitoring offices, expert resources, supervisory bodies, and service providers (Newland 2010, 337).

Finally, states face complex questions about how decision-making and operational powers should be distributed and constrained within border governance institutions that operate externally to individual states - whether involving third party states, non-state actors, or regional and international institutions. Even once the general governance functions of external institutions have been settled - from among the kinds of general functional alternatives just noted - there are still additional questions to be answered concerning the institutional structures required to support these varying governance functions. These questions address matters such as: how the roles of institutional participants are to be delineated and populated; how these participants are to communicate and coordinate their decision-making and activities; and what forms of transparency, accountability, 
rule-compliance, or other political regulation may be required to discipline the exercise of institutional power. In relation to the Australian example outlined above, political controversies have been generated by widespread complaints that externalised border governance suffers from: inadequate compliance with human rights standards, refugee conventions, and other provisions of international law; inadequate transparency in relation to offshore border control operations, by both Australian military personnel and third party state and corporate delegates; and inadequate political accountability and democratic oversight for securitised and regionalised dimensions of border control practices (Fraser 2014).

It is clear from all of this that questions concerning the constitution of control in international border governance are substantively weighty, and occupy prominent positions on real political agendas. Since most normative theorists working on border governance issues well understand the political salience of these questions, there is a puzzle as to why so little attention has been directed towards developing principles and theories to help answer them more systematically. One plausible explanation is that many theorists are inclined to view these questions as important, yet falling under some other kind of scholarly specialisation. In particular they are likely to be classified as questions for practitioner-oriented international policy analysts rather than for normative theorists.

It is certainly true that these questions have received more attention elsewhere, and that answers of a certain kind have been produced within policy analyses of the global governance of international migration. The Global Commission on International Migration articulates a typical answer in its recommendation that:

The governance of international migration should be enhanced by improved coherence and strengthened capacity at the national level; greater consultation and cooperation between states at the regional level, and more effective dialogue and cooperation among governments and between international organizations at the global level. (Global Commission on International Migration 2005, 65) 
Prescriptive recommendations of this kind are helpful as far as they go, and at this level of generality would be consistent with a wide range of normative theories of good governance practice (focused either on moral principles of justice, or political principles of legitimacy of the kind I will discuss below). But since such broadly formulated recommendations leave open questions of how and on what institutional terms such greater 'effectiveness', 'coherence', and 'cooperation' in international border governance can be achieved, they cannot substitute for the more fine-grained principled guidance offered by systematic normative theories.

Moreover, this language of 'effectiveness' and 'coherence' - which is widely applied in these policy analyses - has strongly rationalist connotations. By 'rationalism' in this context, I mean the idea that cooperative political action among states can best be achieved through institutionally harnessing states' instrumental rationality in the pursuit of mutual benefit, or states' communicative rationality in the pursuit of agreement on good policy goals or right institutional rules. In the case of border governance, the appeal to such rationalist grounds for building cooperative international institutions may seem to imply that the challenges are limited to: calculating which institutional designs can most efficiently advance states' shared political goals (including morally motivated ones); or alternatively prescribing institutions for resolving conflicts among states' political goals through rational diplomatic bargaining or deliberative consensus-building.

The mechanisms through which these rationalist logics can help meet institutionbuilding challenges have been elaborated within an influential body of empirical international relations scholarship (Koremenos et al 2001, Risse 2000). Such logics can certainly help to guide the design of international border governance to some degree, as they have done in other governance issue areas. They can only do so, however, to the extent that three simple pre-requisites for rationalist international cooperation and institution-building are satisfied. These pre-requisites are: that states' goals substantively converge - either before or after mutual deliberation; that the content of these shared political goals can be agreed in advance of institution-building action and thus serve as the source of a common motivation for cooperation; and that this motivation can be sustained in a stable fashion over 
time, as the basis for developing and maintaining a functional international border governance apparatus. ${ }^{1}$ And the very limited success achieved to date in building such a governance apparatus through the application of rationalist cooperative logics points towards the fact that, in this issue area, their political pre-requisites are now only minimally satisfied.

Difficulties arise for satisfying each of these three political pre-requisites for rationalist international cooperation and institution building in this issue area. To begin with, states' goals often diverge widely - even after extensive political dialogue and deliberation. Some of these divergences result from conflicts of core state interests - such as those involving issues of national identity and security. Others result from conflicts of core moral values - such as those involving the protection of individual human rights or the collective national right to political sovereignty. These conflicts can be difficult to resolve through rationalist bargaining or consensus-building processes, since fundamental state interests and moral values of these kinds cannot be readily bargained or argued away.

Moreover, the complexity of border governance problems creates an additional motivational obstacle to rationalist international cooperation and institutionbuilding in relation to border governance. More specifically, it is difficult for states to identify clear shared goals in this issue area in advance of undertaking some governance cooperation, and exploring the workability and impacts of different institutions and policies, because the causal processes involved in creating and solving such complex problems can be opaque. A motivational challenge results from this because the instrumental logics associated with rationalist cooperation require a positive assessment of the probable benefits of cooperative action as a precondition for undertaking it, with the consequence that no impetus can be generated for initial exploratory governance ventures in the absence of additional motivational resources (such as from wider social or cultural solidarities). The development of stronger regional cooperation on border governance has been impeded by a dynamic of this kind in the Asia-Pacific, for example, whereby over a

\footnotetext{
${ }^{1}$ I discuss these pre-requisites in more detail in (Macdonald forthcoming, 2015).
} 
decade of Bali Process negotiations about the regional management of irregular migration has failed to yield significant policy or institutional outcomes - in part because regional states lack either a clear understanding of what would constitute an effective solution to the irregular migration problem, or the kinds of broader political relationships that may supply alternative political motives for cooperative political experimentation on these matters (Douglas and Schloenhardt 2012).

Finally, even to the degree that states' governing elites are able to identify shared goals for cooperative border governance initiatives, and articulate clear instrumental rationales for pursuing them, many states can still confront significant obstacles resulting from the more complex and fickle demands of their domestic political constituencies. Border control is an emotionally charged political issue on which the political attitudes of national publics are notoriously susceptible to the vicissitudes of election cycles, economic downturns, nationalist upsurges, media crusades, and opportunistic political parties willing to tailor policy initiatives to these inconstant populist demands. The consequence of this is that states' political commitments on border governance issues are often shifting and unstable, creating difficulties in developing and maintaining over time a functional governance apparatus.

In sum, the important political controversies associated with what I have called the constitution of control raise substantive normative questions about which political theorists should aspire to offer systematic guidance. Moreover, these are distinct from the ethical questions about the justifiability of exclusion that have attracted most theoretical attention with the theoretical literature. Yet these questions cannot be settled adequately through the application of rationalist models of international cooperation and institution-building, of the kind that have dominated prescriptive policy literatures on global governance institutions. Rather, the political project of creating a stronger international border governance apparatus confronts more complex collective action problems, associated with the absence of convergent, clear, and motivationally stable state goals in this issue area. 


\section{Normative principles for guiding the constitution of international border}

control: the role of a 'collective agency' theory of political legitimacy

What guidance can normative political theorists offer in resolving these political controversies concerning the constitution of control in international border governance? Building on the argument just presented, I suggest that theorists can contribute by articulating principles to guide the development of institutional mechanisms that combat the complex collective action problems at the source of weak international border governance capacity. Drawing on theoretical work developed elsewhere (Macdonald forthcoming, 2015), I propose that normative principles of this kind can be helpfully conceptualised as principles of political legitimacy, on what I call a collective agency conception. On this conception, principles of political legitimacy have the regulatory role of combating a set of complex collective action problems; normative political legitimacy is thereby understood as an institutional virtue that supports political institutions' collectively valuable functions by specifying the conditions under which individual agents should support institutions on collective action grounds. More specifically, these collective action grounds take the form of prescriptions for institutional remedies to complex collective action problems that may otherwise impede an institution's collectively valuable functions.

At a conceptual level, this formulation of the idea of political legitimacy may at first appear idiosyncratic, since the collective agency conception of political legitimacy is not (yet) well established within the theoretical literature. Normative theorists currently define it most commonly in moral terms as the 'right to rule' (Buchanan and Keohane 2006). But this moralised conception of political legitimacy is in turn challenged both by new 'realist' political theorists of legitimacy who resist the conflation of political normativity with applied morality (Williams 2005, Sleat 2014), and by critical theorists who insist upon preserving the sociological alongside the moral character of the idea (Habermas 1988, 1996). Elsewhere I argue that there is a broad conceptual framework within which these various familiar usages - alongside my collective agency conception - can be reconciled. In formal terms: The legitimacy of an institutionalised subject $S$ tracks reasons $R$ for 
agents $A$ to engage in conduct $C$ in relation to $S .{ }^{2}$ The collective agency conception conforms to this generic conceptual structure, so is conventional at a broader conceptual level: on the collective agency conception, political legitimacy is identified with the reasons $(R)$ that political agents $(A)$ have to act in support $(C)$ of institutions $(S)$ that facilitate their valuable collective action with others.

Within this broad conceptual framework, the collective agency conception of political legitimacy can then be elaborated by specifying content in each of these substantive dimensions. The institutional subjects of political legitimacy assessments, first, can in principle be any institutions (state or non-state) sustained at least in part through collective political action - which is to say, through the intentional and reasoned support of participants, as distinct from through coercion or unreflective habituation. ${ }^{3}$ Institutions become vehicles for such collective political action to the extent that they are publicly recognised as performing valuable social problem-solving functions through a process of politicisation, whereby an institution is (a) identified by its participants as (actually or prospectively) possessing some functional value as an instrument of some valuable collective action, and (b) subject to a messy mix of contestation and collaboration among participants sharing only partially convergent understandings of the grounds on which the institutions are valuable and warrant support.

Identifying these institutions as the subjects of political legitimacy assessments also enables us readily to identify the relevant agents - whose conduct is to be

\footnotetext{
2 This formulation captures the claim that all analysis of legitimacy is concerned with evaluating an institutionalized subject (such as a state, law, or international governance regime) to determine whether there are sufficient reasons (understood as considerations that count in favour of an action, in the sense of either motivating or justifying it) for particular agents within the institutional scheme (such as citizens, legal subjects, or states) to engage in particular forms of conduct (such as political participation, legal compliance, or cooperative engagement) towards the subject of the legitimacy evaluation. I discuss this definition further in (Macdonald forthcoming, 2015).

${ }^{3}$ More specifically, I take 'collective action' here to be any behaviour that is both: engaged in by some collective of political actors; and jointly intended by at least some sub-set of them. Here I assume that individuals can sometimes be participants in a collective action, without sharing intentions, so long as they are connected to the sub-set of intention-sharing individuals through ongoing material interdependences reflected in collective behavioural patterns of habit and affect. This conception of collective action presupposes a pragmatist account of agency of the kind elaborated for example in the work of Joas (1996).
} 
guided by normative principles of political legitimacy - as any state-based or transnational communities whose support is required to help sustain the functionality of the institutions in question. The political conduct prescribed by these principles, correspondingly, subsumes all the forms of supportive activity through which these participants contribute to sustaining the institution's valuable collective functions.

Finally, we need to specify the normative grounds of principles of political legitimacy on the collective agency conception - that is, the normative reasons that support viewing its principles as action-guiding. These reasons derive from recognising both the political value generated by the institution's primary functions, and the special role of remedial institutions of political legitimisation in bolstering these functions. As such, these principles are normative, but not in the moral sense of principles of justice. Whereas principles of justice prescribe the moral ground rules of a political society (Rawls, 1999; Pogge, 1989), principles of political legitimacy instead prescribe the terms on which institutions' participants should support them if they are to be capable of discharging their collectively valuable functions. These collective agency reasons for action are contingent upon participants' own understandings of the value of an institution's primary value and their motivations to act in pursuit of this value. As such, principles of political legitimacy are normative in what Bernard Williams has called an 'internal' motivational sense - meaning that they are action-guiding only for those political agents who begin their deliberations about whether and when to support an institution with the right 'motivational set' (Williams 1979).

Characterising the normative grounds of principles of political legitimacy in functional rather than moral terms does not mean, however, that these principles necessarily or usually lack moral content. In contrast, it is very common for the value to participants of an institution's primary function to have some significant moral character. Such moral content would be evident, for example, in the case of a sovereign state valued by its citizens as an instrument for social justice, or by international society as an instrument for protecting basic human rights. To the extent that an institution's value to its participants is tied to its moral purpose, 
then normative reasons of political legitimacy and political morality will be closely aligned. But many institutions - operating at both domestic and international levels - are regarded as valuable by their participants for more complex reasons, which may incorporate interest-based and problem-solving political objectives irreducible to moral values; ${ }^{4}$ consequently, the collectively valuable institutional functions that principles of political legitimacy support will rarely be wholly moral in character. It is for this reason that it can be helpful to describe principles of political legitimacy as possessing an autonomously 'political' rather than a straightforwardly 'moral' form of normativity. ${ }^{5}$

Once an institution's collectively valuable functions have been identified by its participants, principles of political legitimacy then operate to support these functions by prescribing institutional remedies to certain complex collective action problems that can otherwise impede successful institutionalised collective action. Three such problems are particularly notable for their pervasiveness across different political contexts, under general background conditions of social pluralism and complexity; these are central to the analysis of institutional collective action problems within rationalist, realist, and pragmatist theoretical literatures, respectively.

First, some rationalists highlight collective action problems resulting from disagreement about valuable ends of institutional action; Buchanan and Keohane (2006) have described this as the 'higher order coordination problem' faced by groups seeking agreement on which institutional arrangement to select, from some mutually beneficial but differentially optimal set of options. A second type of collective action problem can result from the fluidity of the political goals that institutional participants are motivated to support; the realist theorist Raymond Geuss (2008) has highlighted the political pervasiveness of motivational fluidity in political life that results from the indeterminacy of actors' goals in the abstract, and

\footnotetext{
${ }^{4}$ I would argue that this is true also of sovereign states, despite the idealized interpretation of their purpose in articulated in moralized theories of justice or international law.

${ }^{5}$ Various other efforts have been made in recent 'realist' theoretical literature to identify political legitimacy with 'political' rather than 'moral' normativity (Rossi and Sleat 2014), and my claim here resonates closely with these other accounts. My account of the substantive sources of this political normativity is original, however, and cannot be conflated with those of other realist authors.
} 
the responsiveness of these goals to the shifting particularities of varying contexts and moments of political action. Third, some pragmatist theorists highlight another type of collective action problem resulting from the interdependence of means and ends - by which I mean the difficulty of defining goals independently from exploration of ends through material political action. The distinction between means and ends is artificial, these pragmatists argue, since goals can never be defined fully on terms 'that survive the effort to realize them' (Dorf and Sabel $1998,285)$. Identifying the content of principles of political legitimacy within particular institutional contexts thereby requires diagnosing the form that such collective action problems take in given contexts, and prescribing contextually tailored institutional remedies for each institution.

\section{Strengthening Political Legitimacy in International Border Governance}

\section{Institutions}

How, then, can the application of this collective agency conception of normative political legitimacy help to resolve the political controversies outlined above, concerning the constitution of control in international border governance? As noted earlier, I propose that the development and application of normative principles of political legitimacy can help here by prescribing remedial institutional mechanisms to combat the complex collective action problems that now impede the development of stronger international border governance institutions. To identify the content of these prescriptions, it is necessary to answer three key questions, concerned respectively with the functional value of international border governance institutions, the vulnerabilities of these institutions to complex collective action problems, and the character of viable institutional remedies to these problems. In what follows I will address each of these questions in turn. ${ }^{6}$

First, what is the valuable function of international border governance institutions? In other words, what is the point of these institutions, and what is it

\footnotetext{
${ }^{6}$ In (Macdonald forthcoming) I offer a fuller elaboration and defence of the analytic methodology for identifying the content of normative principles of political legitimacy, structured around these questions.
} 
for them to perform their functions well? The authority to make judgments on these questions rests ultimately with the participants in these institutions themselves; but theorists can contribute to their deliberations through interpretive analysis of the justificatory political discourses surrounding the institutions, associated with what I earlier described as processes of politicisation. The aim of such interpretive analysis is to draw out and articulate more explicitly the 'shared understandings' (Walzer 1987, 27) of participants in a collective institutional project regarding its purpose and value, which in turn motivate participants to engage in broadly supportive ways with these institutions. In interpreting these shared understandings, we must examine not what institutional participants say about their guiding moral values or political goals in abstract terms, but rather what justifying reasons participants give for supportive activities towards border governance institutions that they actually undertake. This is because normative principles of political legitimacy (as distinct from moral principles) are grounded in the justifying reasons for institutional participants' materially motivated collective political action, rather than those underpinning their abstract moral belief-systems.

A robust interpretation of the valuable functions of border governance institutions would require much richer empirical analysis than I can supply here; as such, I offer only some tentative interpretive claims, intended to initiate a larger interpretive conversation rather than deliver a definitive account. A provisional reading of these suggests that political support for international border governance institutions is justified principally in relation to the valuable functions of the institution of sovereign statehood itself, as a central institution within international society. By this I mean that whereas many other global governance institutions are devised as instruments for advancing social goods framed in cosmopolitan terms (such as the goods of global economic development, human rights, or global health) border governance institutions are devised principally as instruments for supporting the institutional integrity and capacity of sovereign states themselves. 
This recognition is not sufficient to resolve political controversies stemming from tensions between different social goods that international society expects sovereign institutions in general to advance - such as tensions between the development of national economies and the preservation of national cultures, or between the social rights of citizens and the human rights of refugees (Barkin 1998). But it is nonetheless helpful to view border governance institutions as one case among a wider set of global governance institutions oriented functionally towards the international support of the institutional capacities of sovereign states, since doing so helps to identify analogous institutional cases beyond the border governance issue area from which salient principles and judgments can be drawn as a basis for resolving controversies in the border governance case.

Arguably the most directly analogous global governance institutions, with respect to this shared functional orientation towards the international support of sovereign state capacity, are to be found in the security domain. Questions about the purposes of international security governance institutions, which regulate the use of force by sovereign states within and beyond their territories, have so far received more sustained theoretical attention than those about border governance institutions. Correspondingly, clearer principled frameworks have been developed for understanding the purposes of security governance institutions than have been developed in the border governance case. The most explicit and widely endorsed framework of this kind is articulated in the recent international doctrine of Responsibility to Protect (R2P). This codifies principles for regulating states' use of force based on an interpretation of the relative weight of human rights protections versus political self-determination in accounting for the functional value of state sovereignty, and derivatively, the functional value of the international security institutions that support state capacity (Evans 2004).

The wide international consensus around such principles in relation to security governance entails commitment to a loose hierarchy of values in which protection of the most basic human rights takes highest priority, followed by preservation of the basic forms of collective political self-determination facilitated by the sovereign right of territorial control, followed by the promotion of the diverse 
array of social and individual goods associated with wider human rights standards and economic development. Given their shared functional orientation towards the international support of sovereign state capacity, the core purposes of international border governance institutions can analogously be identified provisionally with the advancement of this same hierarchy of values: basic human rights, basic political self-determination, and wider social and individual goods.

With this provisional account of the functional value of international border governance institutions in place, the next question is: what systemic threats exist to the functional capacities of border governance institutions to advance their purposes? Key tenets of the answer to this question were established earlier, in my discussion of why constitution of control controversies within international border governance have proven so intractable: there, I described some complex collective action problems confronting political efforts to build stronger international border governance institutions, associated with the absence of convergent, clear, and motivationally stable state goals in relation to border control. But through drawing on the account of the functional value of these institutions now also established, it is possible at this point to give a more fine-grained specification of the form that these collective action problems take.

The first collective action problem discussed earlier - the problem of disagreement about valuable ends of institutional action - can now be specified more narrowly as disagreement about how the agreed value hierarchy of basic human rights, political self-determination for collectives, and wider social and individual goods, should be operationalised in the context of border governance institutions. Although the same general value hierarchy may apply within border governance institutions as within other international institutions oriented towards supporting sovereign state capacity (such as certain security institutions), the specifics of the trade-offs among competing values may differ in accordance with the differing threats to core sovereign functions managed by each of these institutional types. Comparing border governance and security governance institutions, for example, we can see that since irregular migration poses a different kind of threat to states' political self-determination and territorial control than does military intervention, 
the range of human rights that should take precedence over political selfdetermination and territorial control in this context may correspondingly vary. For reasons of this kind, significant disagreements persist concerning how the tradeoffs among competing values matters should be made in the context of border governance, and these disagreements pose serious obstacles to successful collective action in the pursuit of stronger border control institutions.

The second collective action problem discussed earlier - the fluidity of the political goals that institutional participants are motivated to support - can be specified more narrowly as a problem with maintaining stable motivational commitment to the specific hierarchy of values guiding the development of stronger international border control institutions. Even though states and their citizens may be committed in the abstract (under ideal deliberative conditions) to a value hierarchy in which basic human rights protections trump other kinds of social goods, these commitments are not motivationally strong within the more concrete contexts of political action in which support for international border governance institutions is required. The fact that so many political parties within liberal democracies are willing to abandon principled (including sometimes legal) commitments to human rights protections for refugees and other migrant groups in the pursuit of short term electoral advantage, and the willingness of so many citizens to reward this political conduct at the ballot box, illustrate one concrete way in which this problem of motivational fluidity can be manifested.

The third collective action problem identified earlier - the interdependence of means and ends - can more narrowly be specified as a problem stemming from lack of clarity about how the in-principle and abstract value hierarchy of basic human rights protection, political self-determination for collectives, and wider social and individual goods can best be pursued through concrete institutional action. Given the complexity of social factors shaping both causes and effects of population movements across borders, it will not be possible to specify which institutional arrangements are able to achieve the most desirable balance among the competing political values within this hierarchy (or correspondingly to specify in practical terms the character of this desirable balance itself) except after some 
extensive political experimentation with available institutional alternatives. Yet without a clear ex ante instrumental rationale for the development of any one concrete institutional initiative, some alternative motivational resources will be necessary to provide political impetus for political commitment to institutional development in the required experimental mode.

Following from this rough account of the collective action problems impeding the development and operation of the valuable functions of border governance institutions, the final question to be answered in specifying standards of political legitimacy for these institutions is: what plausible institutional remedies are available for these collective action problems? Taking the problem of disagreement first, some progress could potentially be made through the articulation of more formally codified principles specifying the valuable functions of border governance institutions. The regulative function of such principles would be broadly analogous to the formally codified principles of R2P in relation to security governance institutions - which is not to prescribe or prohibit specific policies or operations, but rather to orient and focus political deliberations about specific policies and operations upon an agreed basic hierarchy of values.

Although formally codifying principles of this kind could not be expected to resolve deep disagreements about the purposes of border governance institutions, it could likely help to direct political focus towards big-picture problems and common values. In doing so, it could help resolve some deeper factional divisions that can result when participants focus in deliberations on narrow, short-term, and interest-based political considerations. Relatedly, it may be helpful to ensure that any deliberative processes established for the development of such formalised principles accord prominent roles to high-level international and civil society leaders drawn from outside the migration sector. Strong representation of actors with political mandates and responsibilities extending beyond border governance issues may similarly help sustain a deliberative focus on big-picture and common values, and in doing so circumvent some of the factional divisions operating within narrower migration policy-making settings. 
Collective action problems associated with the fluidity of political goals, second, could potentially be remedied through the development of stronger systems of political accountability within border governance institutions, functioning to hold border governance policies and operations, at state, regional, and international levels, more systematically to the normative standards embodied in formalised principles. Mechanisms of accountability could help to strengthen collective action in support of an agreed hierarchy of functional values by imposing some political costs or sanctions upon political actors who fail to support them. The character of such sanctions could range from the reputational to the more material - in the latter case, for example, through linking actors' border governance cooperation behavior systematically, predictably, and publicly to other kinds of political and economic benefits (such as favourable trade relationships, for example). These would need to vary in accordance with the different motivations and vulnerabilities of the various state, non-state, and international actors whose support for the valuable functions of these governance institutions these mechanisms aim to secure.

While the significant benefits to institutional functions associated with strong accountability practices have been widely discussed in relation to many forms of international institutions, leading to many recent pro-accountability reforms at international levels (Grant and Keohane 2005), there has been much less momentum towards strengthened political accountability within border governance institutions. As a result, accountability structures within these institutions are currently weak, and leave significant scope for pro-accountability reform. The most critical pre-requisite for strengthening accountability mechanisms within these institutions would be greater transparency in both the policy-making and operational dimensions of border governance institutions, which function at present in much greater secrecy than other high profile international governance institutions - reinforced by the political appeal to 'national security' discourses as grounds for restricting avenues for public scrutiny. 
Finally, what institutional remedies are available for the collective action problems associated with the interdependence of means and ends in the translation of abstract justifying principles for border governance institutions into concrete prescriptions for institutional action? One important contribution could be made here by more systematic incorporation of experimentalist governance tools within border governance institutions - where experimentalism is understood as an institutionalised process of inquiry-based problem-solving, devised to tackle collective action problems of precisely this kind. Theoretical understandings of experimentalism were developed influentially by classical American pragmatist John Dewey, and have been recast for contemporary institutional applications through the work of Michael Dorf and Charles Sabel, among others (Dorf and Sabel 1998, Sabel and Zeitlin 2008). In many transnational governance contexts, a range of experimentalist mechanisms have helped support the development of valuable institutional functions by fostering 'participatory and multilevel collective problem solving', in which the problems (and the means of addressing them) are 'framed in an open-ended way, and subjected to periodic revision by various forms of peer review in the light of locally generated knowledge' (Búrca, Keohane, and Sabel 2014, 477). The development of more extensive experimentalist governance mechanisms of this kind may similarly help to support valuable functions within the context of international border governance, as a supplement to the more rigid rule-enforcement models that have thus far predominated as institutional vehicles for international border governance.

\section{Conclusions}

In this article I have highlighted an important set of normative controversies arising in international border governance that have been largely neglected thus far by political theorists, and sketched a systematic theoretical approach to resolving them. I have called these constitution of control controversies, and shown how they rise to prominence once we challenge the assumption that each sovereign state possesses the institutional capacity to control its borders in accordance with any moral principles its citizens may choose to endorse (an assumption latent within normative debates focused predominantly on the ethics 
of exclusion). Resolving constitution of control controversies is of critical importance even for theorists interested ultimately in the ethics of exclusion, because identifying the correct ethical principles for regulating population movements across borders will be of greater use once we have solved the problem of how to build and sustain materially functional border governance institutions through which to enact our ethical principles.

Significant progress can be made in resolving constitution of control controversies, I have argued, through applying a collective agency conception of normative political legitimacy, which accords principles of political legitimacy the regulatory role of combating a set of complex collective action problems that may otherwise impede an institution's collectively valuable functions. This theory of normative political legitimacy raises many larger philosophical questions - about the concept of legitimacy, the character of political normativity, and the substantive content of normative standards of legitimacy in different political contexts - which I have not answered fully here. ${ }^{7}$ But insofar as the value of any theory should be judged in part by its utility in solving important problems, my analysis here of the theory's utility in resolving serious political controversies in relation to international border governance should nonetheless be seen to lend some substantive support to the theory.

The concrete prescriptions I have sketched for strengthening the political legitimacy - and thereby the functional strength - of border governance institutions are merely provisional and illustrative, and intended more to stimulate a larger theoretical conversation about political legitimacy in border governance than to offer definitive solutions. Moreover, the content of these prescriptions overlaps significantly with those advanced within wider debates about political legitimacy and good governance within international institutions more generally, and in other functional domains such as global economic governance. What is new and significant here, though, is a systematic argument for recognising the importance of developing legitimisation mechanisms of these familiar kinds within

\footnotetext{
7 This task is undertaken elsewhere, in (Macdonald 2015).
} 
the domain of international border governance, where such claims have previously been little considered on theoretical agendas.

\section{References}

Abizadeh A (2008) Democratic theory and border coercion: No right to unilaterally control your own borders. Political Theory 36(1): 37-65.

Akakpo C and Lenard P (2014) New challenges in immigration theory: an overview. Critical Review of International Social and Political Philosophy 17(5): 493-502.

Australian Human Rights Commission (2013) Asylum Seekers, Refugees and Human Rights: Human Rights Commission Snapshot Report. Available at https://www.humanrights.gov.au/sites/default/files/document/publicatio n/snapshot report 2013.pdf (accessed 15 April 2015).

Barkin, JS (1998) The evolution of the constitution of sovereignty and the emergence of human rights norms. Millennium: Journal of International Studies 27(2): 229-252.

Betts A, ed (2011) Global Migration Governance. Oxford: Oxford University Press, 2011.

Blake M (2014) The right to exclude. Critical Review of International Social and Political Philosophy 17(5): 521-537.

Brouwer A and Kumin J (2003) Interception and asylum: when migration control and human rights collide. Refuge: Canada's Journal on Refugees 21(4): 6-24.

Buchanan A and Keohane R (2006) The legitimacy of global governance institutions. Ethics \& International Affairs 20(4): 405-437.

Carens J (1987) Aliens and citizens: The case for open borders. The Review of Politics 49(2): 251-273.

Carens J (2003) Who should get in? The ethics of immigration admissions. Ethics \& International Affairs 17(1): 95-110.

Carens J (2013) The Ethics of Immigration. Oxford: Oxford University Press.

De Búrca G, Keohane R and Sabel C (2014) Global Experimentalist Governance. British Journal of Political Science 44(3): 477-486.

Dench J and Crépeau F (2003) Introduction: Interdiction at the expense of human rights: A long-term containment strategy. Refuge: Canada's Periodical on Refugees 21(4): 2-5.

Dorf M and Sabel C (1998) A constitution of democratic experimentalism. Columbia Law Review 98(2): 267-473.

Douglas J and Schloenhardt A (2012) Combatting migrant smuggling with regional diplomacy: An examination of the Bali Process. Research Paper, Migrant Smuggling Working Group, University of Queensland. Available at http://www.law.uq.edu.au/documents/humantraffic/migrantsmuggling/regional-cooperation/Douglas-Schloenhardt-Bali-Process.pdf

Economist (2013) Secure enough. The Economist 22 June 2013. Available at http://www.economist.com/news/united-states/21579828-spending- 
billions-more-fences-and-drones-will-do-more-harm-good-secure-enough (accessed 15 April 2015).

Evans G (2004) The responsibility to protect: Rethinking humanitarian intervention. In The American Society of International Law Proceedings of the Annual Meeting (American Society of International Law), pp. 78-89.

Farrell P (2014) Ricky Muir vote reinstates TPVs and hands Coalition hollow asylum victory. The Guardian (Australian edition) 5 December 2014.

Available at http://www.theguardian.com/australianews/2014/dec/05/ricky-muir-vote-reinstates-tpvs-and-hands-coalitionhollow-asylum-victory (accessed 15 April 2015).

Fraser M (2014) Manus Island: So many questions, one simple solution. The Age, February 12014 . Available at http://www.theage.com.au/comment/manus-island-so-many-questionsone-simple-solution-20140220-333sn.html (accessed 15 April 2015).

Geddes A (2005) Europe's border relationships and international migration relations. Journal of Common Market Studies 43(4): 787-806.

Geuss R (2008) Philosophy and Real Politics. Princeton: Princeton University Press.

Global Commission on International Migration (2005) Migration in an Interconnected World: New Directions for Action. The Commission. Available at http://www.queensu.ca/samp/migrationresources/reports/gcimcomplete-report-2005.pdf (accessed 15 April 2015).

Grant R and Keohane R (2005) Accountability and abuses of power in world politics. American Political Science Review 99(1): 29-43.

Habermas J (1988) Legitimation Crisis. Oxford: Polity Press.

Habermas J (1996) Between Facts and Norms: Contribution to a Discourse Theory of Law and Democracy. Cambridge, MA: MIT Press.

Harns C (2013) Regional Inter-State Consultation Mechanisms on Migration: Approaches, Recent Activities and Implications for Global Governance of Migration. Migration Research Series 45, International Organization for Migration. Available at http://publications.iom.int/bookstore/free/MRS45 EN 10May2013.pdf (accessed 15 April 2015).

Joas H (1996) The Creativity of Action. Chicago: University of Chicago Press.

Keohane R (1988) International institutions: Two approaches. International Studies Quarterly 32(4): 379-396.

Koremenos B, Lipson C and Snidal D (2001) The rational design of international institutions. International Organization 55(4): 761-799.

Lopez C (2003) Australian immigration policy at the centenary: The quest for control. Georgetown Immigration Law Journal 18(1): 1-69.

Macdonald $\mathrm{T}$ (forthcoming) Institutional facts and principles of global political legitimacy. Journal of International Political Theory.

Macdonald T (2015) Global Political Legitimacy: A Normative Theory of World Politics. Manuscript in Preparation. 
Marchi S (2010) Global governance: Migration's next frontier. Global Governance: A Review of Multilateralism and International Organizations 16(3): 323-329.

Miller D (2010) Why immigration controls are not coercive: A reply to Arash Abizadeh. Political Theory 38(1): 111-120.

Missbach A (2014) Doors and fences: Controlling Indonesia's porous borders and policing asylum seekers. Singapore Journal of Tropical Geography 35(2): 228-244.

Newland K (2010) The governance of international migration: Mechanisms, processes, and institutions. Global Governance: A Review of Multilateralism and International Organizations 16(3): 331-343.

Pollak J and Slominski P (2009) Experimentalist but not accountable governance? The role of Frontex in managing the EU's external borders. West European Politics 32(5): 904-924.

Rawls J (1999) A Theory of Justice Revised Edition. Cambridge, MA: Harvard University Press.

Risse T (2000) Let's argue!": communicative action in world politics. International Organization 54(1): 1-39.

Rossi E and Sleat M (2014) Realism in normative political theory. Philosophy Compass 9(10): 689-701.

Sabel C and Zeitlin J (2008) Learning from difference: the new architecture of experimentalist governance in the EU. European Law Journal 14(3):271327.

Searle J (2005) What is an institution. Journal of Institutional Economics 1(1): 1-22.

Seglow J (2005) The ethics of immigration. Political Studies Review 3(3): 317-334.

Silverman S (2014) Detaining immigrants and asylum seekers: a normative introduction. Critical Review of International Social and Political Philosophy 17(5): 600-617.

Sleat M (2014) Legitimacy in realist thought: Between moralism and realpolitik. Political Theory: 42(3): 314-337.

Walzer M (1987) Interpretation and Social Criticism. Harvard: Harvard University Press.

Williams B (1979) Internal and External Reasons. Reprinted in Williams B Moral Luck: Philosophical Papers 1973-1980. Cambridge: Cambridge University Press: 101-13.

Williams B (2005) In the Beginning Was the Deed: Realism and Moralism in Political Argument. Princeton: Princeton University Press. 


\section{University Library}

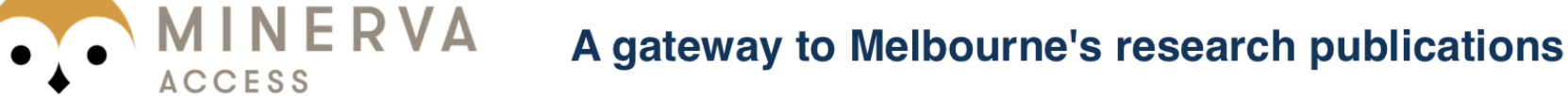

Minerva Access is the Institutional Repository of The University of Melbourne

Author/s:

Macdonald, T

Title:

Political legitimacy in international border governance institutions

Date:

2015-10-01

Citation:

Macdonald, T. (2015). Political legitimacy in international border governance

institutions. EUROPEAN JOURNAL OF POLITICAL THEORY, 14 (4), pp.409-428. https:// doi.org/10.1177/1474885115589875.

Persistent Link:

http://hdl.handle.net/11343/292070 